Journal of Social Sciences (COES\&RJ-JSS)

ISSN (E): 2305-9249 ISSN (P): 2305-9494

Publisher: Centre of Excellence for Scientific \& Research Journalism, COES\&RJ LLC

Online Publication Date: $1^{\text {st }}$ October 2015

Online Issue: Volume 4, Number 4, October 2015

https://doi.org/10.25255/jss.2015.4.4.945.951

\title{
THE STUDY OF PREPARATION STRATEGY OF SENIOR HIGH SCHOOL (SMA / MA) GRADUATES IN PASURUAN
}

\author{
HM Zainuddin, Muslihati, IM Hambali \\ State University of Malang, Indonesia
}

\begin{abstract}
:
Senior High School (SMA) is the formal education system of intermediate level after the junior secondary level that prepares graduates to continue their education to a higher level (college). In a policy perspective, senior high school (SMA) graduates are prepared to continue their education. Parents and the Junior High School (SMP) should prepare them comprehensively and independently. This study is intended to describe and analyze the various factors which become the references for educational success in senior high school (SMA/MA), such as the awareness of parents to determine the education of their children, the awareness of the students about the condition of a future which are full of challenges, the quality of education at the senior high school (SMA/MA) especially in strengthening educational character and the quality of workers as the need of workplace, including the role of government in addressing these conditions. The studies obtained from schools, namely accommodation and relevance of senior high school (SMA) curriculum development to the needs of workers in a good quality industry, the principal has a great commitment, availability of production units, partnerships with businesses and industries (DUDI), have a good simultaneous cooperation between vocational high school (SMK) and senior high school (SMA).
\end{abstract}

Keywords:

Preparation, graduates, senior high school

\section{Citation:}

Zainuddin, HM; Muslihati, Hambali, IM (2015); The study of preparation strategy of senior high school (SMA / MA) graduates in Pasuruan; Journal of Social Sciences (COES\&RJ-JSS), Vol.4, No.4, pp: 945-951; https://doi.org/10.25255/jss.2015.4.4.945.951. 
Senior High School (SMA) is the formal education system of intermediate level after the junior secondary level that prepares graduates to continue their education to a higher level (college). In a policy perspective, Senior High School (SMA) graduates are prepared to continue their education. Parents and the Junior High School (SMP) should prepare them comprehensively and independently. A fact that is always as an indicator of obstacle for senior high school graduates preparation is unabsorbed of the graduates for the industries. There are many senior high schools and college graduates cannot be recruited by the industries because of their low quality. Moreover,7.24 million unemployed (August 2012), $19.47 \%$ are senior high school graduates and $12.11 \%$ are graduates of higher education. It shows that the competence and skills acquired by graduates of senior high schools and universities have not been able to meet the demands of quality and competence required by the industries. Therefore, improvement in quality must be done, including preparing senior high school graduates in the field of local skills and the development of attitude or productive character. Therefore, local content is not just as the subject that is "plastered", but local content is truly as the entrance of independent personal development program with environmental concept.

\section{METHODS}

The research approach used in this study is an evaluation research with a "Process-Audit", using quantitative and qualitative methods and quantitative with explorative survey. Through this approach will be obtained the data to reveal the relevance and suitability between the competencies that have been procured by senior high school graduates with the competencies required by industry, the gap between the competency of graduates with industry needs, chain conversion required for senior high school graduates who work in the manufacturing industry and the potentiality of vocational school (SMA technology) in realizing teaching factory.

This research was conducted in order to assess and evaluate the relevance of senior high school with the needs of industries in Pasuruan. This study uses an evaluation research design with a "Process-Audit", using quantitative and qualitative methods and quantitative methods explorative survey. Evaluative research conducted in order to gather data on the performance in the implementation of a policy which can be used to improve policy implementation through relevant policy recommendations. In the implementation, this study used mixed methods, namely quantitative and qualitative methods. Quantitative method is used to describe components of policy and its realization to the implementation of basic education (in this case the principal and teachers) based on the criteria which are outlined by the supportive government policies. The use of quantitative methods produce comprehensive picture toward the implementation of senior high school (SMA) education (including the process and results) as well as the holder of quality control efforts at the school level. Finally, this study can provide a comprehensive profile of the implementation of senior high school (SMA) education as an indicator of the quality and relevance of education.

The primary data was obtained by meeting the respondent or data sources to complete a questionnaire and did the observation and documentation in the senior high school (SMA), the manufacturing industry and repair shop / chosen manufacturing industry as samples. Respondents or sources of data come from senior high school (SMA), industry and entrepreneur. They are principal of senior high school (SMA), industry leader, and business owners.

The population in this study is the senior high school (SMA). Sampling was done by random sampling. The next step determines the senior high school that will be chosen 
as a sample. Meanwhile the manufacturing industry and entrepreneurs are chosen based on the relevance with the fields of expertise in the related senior high school (SMA). Industrial categorizations based on the number of workers that is owned by the industry. While entrepreneurs are used as a source of data is the senior high school alumni who opened the business independently.

Data collection instruments in this study were 1) questionnaire, 2) documentation, 3) guidelines for observation, and 4) interviews. Questionnaire is used to obtain data on the performance of the teachers with educator certified. The focus of data to be captured is about the process and outcomes of learning, teachers' efforts to improve the quality of learning (through teacher innovative works, action research and lesson study), the commitment of teachers in implementing self-development through teacher associations, their participation in education and training independently, as well as learning facilities held as an effort to strengthen the quality of learning, sources of readings from both print and electronic sources.

The data to be collected includes: (a) the accommodation of senior high school curriculum toward the interests of industry, (b) the relevance of the development of senior high school curriculum to the needs of workers in the industry, (c) Development of human resources (teachers and tool man) in school and its relevance to the interests of industry, ( d) Development of infrastructure in SMA and its relevance to the interests of industry, (e) Commitment of the school leaders to the production unit has supported the industry, (f) high school orientation towards the product (product oriented), (g) availability of specialized staff for the senior high school to seek an order to the industry / community, (h) the support of school policies on industries production unit, (i) the support of SMA products to industry (Out sourcing industry to high school through the school unit production), (j) Documenting the number of high school graduates who work in informal / formal sector (including small entrepreneurs; part time repair shop), (k) the support of SMA results practice product to industry around the school (the results practice product that are worth selling), (1) The level of salable final product of senior high school project (in Competency Test), (m) the knowledge of industry around the school to potential data of SMA competency test, (n) the training held by school about entrepreneurship in maintenance and repair workshop, (o) The rate of inadequate school facilities and infrastructure practice for the activities of production units, (p) The number of regular customers owned by school for the results of production units, (q ) marketing network of school production units, (r) shop (show room) owned by the school to sell the units of production or services directly to the buyer, (s) the promoting effort toward the result of $t$ production unit, $(\mathrm{t})$ the schools effort to conduct partnership with the industry or company to carry out some of the work of the industry, (u) Production Unit Ownership business license or the law, (v) level of professionalism of the management of the Production Unit as a company, (w) the schools effort to maintain product quality through quality control processes, (x) syllabus are always up dated in accordance with the needs of the industry. Data were analyzed using descriptive statistical techniques, and qualitative analysis that provide an adequate explanation for the existing quantitative data. To reveal the relevance of senior high school graduates with the manufacturing industry used growth accounting model based on secondary data. Whereas to determine the compatibility between competencies that have been trained by senior high school to its graduates with the competencies required by industry, the gap between the competency of graduates with industry needs, chain conversion required for senior high school graduates who work in the industry as well as the potential of senior high school as a teaching factory used quantitative descriptive analysis of primary data. 


\section{RESULTS}

School Data

Accommodations and relevance of senior high school curriculum development to the needs of the workers in the industry

Accommodations and relevance of senior high school curriculum development aimed at realizing the senior high school graduates who can have a good competence (soft and hard skills) as well as the mental attitude that is relevant to the needs of the employee. Although the concept of a senior high school education more prepared to go to college, but in fact there are many senior high school graduates prefer to work and do not continue their education to college. This is the reason why senior high school, in addition to prepare graduates to enter college also prepares them to enter the workplace and industry. Senior high school (SMA) does not accommodate the interests of the industry, including the relevance of the curriculum and the teachers. The curriculum has been designed in accordance with the provisions of the ministry of education and culture are not accommodate the interest that illustrated the need of senior high schools (SMA) in preparing their graduates to come in to the workplace and industry. If there are cases in certain areas, where many senior high school graduates work as industrial employee, that regions should undertake a special breakthrough that makes senior high school as a multipurpose institution.

The principal commitment

Many school leaders have not yet commitment for students who do not go for college. It is an indicator of whether the school has been prepared a strategy for senior high school graduates. This fact is a consequence of the basic concepts that emphasize senior high school graduates to go to higher education. If there is a commitment to regional leaders to see the reality rather than the basic concepts, actually the region leader through the relevant office may make regulations that can create a sense of security for senior high school graduates who in fact did not continue to higher education. Thus, related office (Regional Office of Education Department) should be systematically to survey and monitor the graduates of all levels of formal education.

The availability of Production Unit

There is no high school which has a production unit as a means of learning. The availability of production units in senior high school became one of indicators for the preparation efforts of the school to the possibility of the graduates who do not go to college. The absence of production units in almost all senior high school is actually a fact that senior high school does not prepare it well. The possibility of many senior high school graduates are employed or unemployed gave further important reason to realize that unit in the senior high school with more than $30 \%$ of its graduates are not continue their study to higher education. There is no special staff that concern to promote the graduates to the industries. The staff referred to in this research is the officer who is specifically given the task by the principals, and its position can be a vice principal or counseling teacher. Special staff will record the data of students who do not continue their study to college, then followed by the emergence of efforts to offer the graduates to the industries, even if possible they will be given an authorization to make a particular program. Through this special staff, schools can develop a network and partnership with companies.

Partnership with Business and Industry (Industrial-School Relation)

The reality shows that most of the senior high school does not have a network with the company. This is why most students who do not continue their study to higher 
education, they will unemployed. If the existing staff can be fully utilized, then their existence that allows the formation of a network between schools and companies become real. And it can continue to supply the production of certain materials as a result of a unit production. The fact shows that there is no school that has a network to supply products to the industry. Supplying products to the industry can be raw materials (feedstock) for companies that required local raw materials or semi-finished materials. If there is no effort to establish partnership between senior high school (SMA) and the company, the unemployment will be higher. And the other fact is that there is no promotion of the school product.

\section{Simultaneous Cooperation between SMA-SMK (Public High School and Vocational} School)

It is possible to implement the cooperation between senior high school (SMA) and vocational schools (SMK), vocational school (SMK) trains senior high school (SMA) students who want to get work instead of going to college meanwhile senior high school (SMA) trains vocational school (SMK) students who want to go to college as a replacement for working. This is a breakthrough for schools to give special attention to the graduates.

\section{INDUSTRY DATA}

Some data that can be collected are (a) Some companies prefer graduates of vocational school (SMK), (b) some companies prefer graduates from senior high school (SMA), (c) the increasing of the workers are not routine, but depending on the number of vacancies due to retirement of workers, (d) there are no anecdotes / events showing the weaknesses of workers who graduated from Senior High School, (e) The need for training interview and try out a psychological test, (f) the company prefers to worker from the society around the company, (g) There are no representatives of schools that specifically promote the graduates (such as SMK 8 Malang), (h) The character of the work depends on the supervisor, (i) A number of companies do not allow the product to be produced by schools, (j) A number of companies are choosing a senior high school graduate because they have no skill/ relevant competencies or linear, SMA students can be trained faster, $(\mathrm{k})$ Some companies require basic skills possessed by workers, (l) senior high school graduates who have the skills certificates will be more readily accepted in the industry

\section{DISCUSSION}

High School Curriculum Development Accommodation and Relevance was aimed at producing skillful graduates in terms of soft and hard skills as well as mental attitude which are relevant to the need of industry. Therefore, the coverage of curriculum must also include competency required by industry. Such inclusion will support the theory that an attitude of people toward an obyek functions as the linkage between the respond and the object (Asjen and Fishbein, 1988:28).

The joint program between public high schoool (SMA) and vocational high school (SMK) can be managed by making the vocational high school students teach public high school students who do not persue for the undergraduate degree and the public high school students teach vocational high school students who want to persue to their higher level. Such program has been a new strategy to give attention to high schools graduates. This complies what Saipudin(2014) found that there was a positive result between training and self eficacy towards being entrepreneurs after training. Therefore, early preparation for high school students to face the field of works is very important. Feiock(2009) says that social capital can contribute to formulate and to make working process through cost minimalization Thus, those high school students who stayed near the 
company have nore opportunity, than those who do not due to having able to minimalize cost. This implies that it is important to make early ready to work preparation for high school students. Widodo (2014) suggests that entrepreneurship education model shall be suited and managed in three aspects, which are characters, education, and skills. Whereas, Fajri (2014) states that social model implementation can be in the form interaction, similarity of cultural values, networking, and mutual relationship which are attached to those voluntarily participated in team work. In fact, it has been found out that (a) several companies tend to choose vocational high school graduates, (b) some companies like to choose public high school graduates, (c) recruitments are done on the basis of the vacant position availability, but not done anytime, (d) there are not many occations showing weaknesses of the work force graduated from public high school. (e) There is a need of practicing interview and psychotest tryout, (f) recruitment prioritizes those living near the company, (g) there has not been school representative who intentionally offer work forces, (h) working characters depends on supervisors, (i) some companies realize that their products cannot always be resulted from partnership with schools, (j) several companies tend to choose publick high school graduates by assuming that they are easily trained eventthough they do not have adequate compertency when they are recruited, $(\mathrm{k})$ some companies need candidates to have basic skills, (l) public high school graduates having skill certificate will have more opportunity to be easily accepted in industrial field. Henderson dan Stephan (2010) found out that (a) entrepreneurship was sistematic, (b) entrepreneurship has big impacts, and (c) the impact of entrepreneurship was greater in the crowded area.

\section{RECOMMENDATIONS}

From the data presented above, it can be suggested as follows: (a) it is required subjects in senior high school that allows students to get work experience, (b) besides work experience, SMA also have to give mental preparation so that students who do not go for college can be prepared to run business rather than jobless, (c) the school should also establish a special staff in charge of offering graduates as candidates of worker. Including strengthening counseling teacher for conducting individual planning service more intensively, (d) it is needed to be established regulations that govern the cooperation of vocational-school and senior high school which deals with SMA students who do not continue for college and SMK students who want to continue for college. (e) Training personal development and character, psychological test, tryout should be given to students in grade 12, (f) Schools need to detect early to students who predicted not to go to college then they will obtain special training besides preparing for national exam, $(\mathrm{g})$ preparing the competency and basic skills as the provision of entering the industry, $(\mathrm{h})$ There is a kind of model that has been implemented by SMKN 8 Malang, where supply graduates to companies very intensively, so that school knows students who do not work even though the amount is not higher, (i) Particularly in order to prepare graduates who are interested in entrepreneurship, the school needs to establish a production unit, $(\mathrm{j})$ in addition, the school also needs to equip students with entrepreneurship subjects.

\section{References}

Asjen dan Fishbein1988.Attitudes personality and behaivior.Dorsey Press: Chicago Saipudin, A.2014.Efektifitas pelatihan dan Efikasi dalam meningkatkan prilaku Kewirausahaan.Bandung: Lemlit UPI. 
Fajri, D.2014.peran Modal social dalam kerjasama antar Daerah.Bandung: Lemlit ITB

Feiock.R.C.2009.Metropolitan Governance and Institusional Collektive Action. Urban Affairs Reviers.44(3).

Faisal, S. dan H.S.Mundzir.2006. Sosiologi Pendidikan.Malang: Penerbit Fakultas Ilmu Pendidikan Univeritas Negeri Malang.

Gardner.H.2006 ${ }^{\mathrm{b}}$.Five Mind for The Future. Boston.MA:Harvard Business School Press. Henderson,J.dan Stepan W.2010.Entrepenuenrs and Job growth: Probing the Bondarnes of time and space.Economic development.vol 24.1

Sallis,E. 2011.Manajemen Mutu Terpadu Pendidikan. Yogyakarta:Penerbit IRCiSoD. Widodo, S2014.Model pendidikan Kewirausahaan bagi santri untuk mengatasi pengangguran di pedesaan.Bangkalan: Lemlit Trunojoyo 